ELIAS SEBSIBE HAILE,

\title{
QUALITATIVE INQUIRY INTO THE PRACTICE OF INSTRUCTIONAL LEADERSHIP AND TRANSFORMATIONAL LEADERSHIP IN PUBLIC SECONDARY SCHOOLS OF ADDIS ABABA, ETHIOPIA
}

\begin{abstract}
Educational or school outcomes are strongly associated with the quality and/or relevance of leadership style used by principals and its possible influence on the level of teacher job satisfaction. To attain the goals of the school, the principal needs to engage in an effective leadership style to inspire and encourage teachers. The aim of this study is to investigate the public school leadership practice in the theoretical view of instructional leadership and transformational leadership styles. Both theories have been found to encompass leadership practices that enhance teacher job satisfaction and student achievement. Qualitative case study research design was used to investigate the issue. The study participants were selected purposefully from the public school principals and teachers. In this research 34 participants were selected, 24 teaches and 10 principals from the 65 schools. The research participants were interviewed using the semi-structure interview quastions. The data analysis was done concurrently with the interview sessions were takes place. ATLASti version 8 was used to organized and generate the codes and themes of the study. Based on the themes the study results were discussed. Addis Ababa public school principals were not fully implemented the instructional leadership and transformational leadership behaviors. The school leadership and management practice was interfered by politicians to execute ruling party interest in the school. Principals were not assigned by their profession and performance, afflation to the ruling party was mandatory to be the school principal. As the result of this teachers were not satisfied and motivated. Teaching and learning was not effectively supported by the school leaders. Thus, study participants perceived that the school leadership was traditional and not practice effective school leadership style like instructional and transformational leaderships style. The study participants stated that transformational leadership behaviour and instructional leadership style have a positive impact on teacher job satisfaction, work commitment and better school performance. In this study, as suggested by the teachers, transformational leadership is a favourable leadership style in order for schools to become effective in their activities. They also agreed that such leadership behaviour is strongly related to improving student achievement.
\end{abstract}

Key word: instructional leadership; transformational leadership; public secondary school; effective school leadership.

\section{INTRODUCTION}

Education develops knowledge and skills of members of society, ensuring the betterment of their environment for future generations. Schools, seen as formal educational organisations, are bounded within a community (Elias \& Girum, 2018). Schools are organised by human resources (teachers, principals, and staff), consist of physical inputs (buildings, teaching materials) are funded in various ways and are guided by policies and the curriculum. However, inspired and dedicated teachers are key to ensuring quality and relevant education that positively affect educational success (Fekede, 2015: 169). Thus, schools are vital organisations for the education of a country's youth, and by default, school leadership remains responsible to ensure quality of education through teacher motivation and responsibility (Tesfaw, 2014: 2).
Educational or school outcomes are strongly associated with the quality and/or relevance of leadership style used by principals and its possible influence on the level of teacher job satisfaction. To attain the goals of the school, the principal needs to engage in an effective leadership style to inspire and encourage teachers (Eyal \& Roth, 2011:271; Nir \& Hameiri, 2014). Thus, school principal leadership style and teacher satisfaction play critical roles in the achievement of educational outcomes (Ibrahim \&Wahab, 2012). In harmony with this statement, Hallinger (2007) and Leithwood and Sun (2012:420) report that, in an educational organisation, in which appropriate leadership styles are used by principals and where the staff is highly motivated, the goals of the organisation are very likely to be achieved. Likewise, school success significantly depends on the level of job satisfaction of teacher and teachers' readiness to accomplish the goals 
of school (Aydinet al., 2013). Among the possible causes for public schools' success, are central variables such as principal leadership styles and teacher professional satisfaction.

According to Davis and Wilson (2000), Price (2012) and Tesfaw (2014), the effectiveness of schools mainly depends on the quality of the leader or the ability of the principal to organise and lead the school. Various studies have reported that principals' use of different leadership styles, for example transformational leadership and these leadership styles can be linked to teacher job satisfaction (Bass, 1999; Selamat, Nordin \& Adnan, 2013). Therefore, school leaders should identify and apply leadership practices that encourage good working conditions, collaboration, a shared mission and job satisfaction among teachers.

According to resources such as Abdo (2000), the Centre for British Teachers and VOS (2008) and Mengistu (2012), the education system in Ethiopia is currently challenged by a high teacher turnover, low number of capable teachers, low levels of motivation, low teacher morale and poor quality of the working environment. Fekede (2015), Mengistu (2012) and Tesfaw (2014) have all reported that there is low level of teacher satisfaction and high turnover among public secondary school teachers. There seems to be a dearth of research in Ethiopia, which investigates the influence of principal leadership styles (instructional and transformational leadership) on teacher job satisfaction.

The study explores to understand the practice of school leadership style and teachers job satisfaction in public secondary schools in Addis Ababa, Ethiopia. School leadership practice has impact on the teacher job satisfaction. According to Zorlu and Arseven (2016), Bush and Glover (2014), school leadership is the process of influencing, motivating teachers towards the better achievement of the school. Thus, principal leadership style is the main cause for teachers' job satisfaction, commitment, and performance. Among different school leadership styles this study focused on the most prominent leadership styles of instructional leadership and transformational leadership (Bayler, 2012). Regarding, job satisfaction, Herzberg's two factors theory was the base for examining the study objectives (see chapter two).

\section{School Leadership Theories.}

Instructional school leadership. Instructional leadership as models emerged in the early 1980s from early research on successful and unsuccessful urban elementary schools serving poor communities in North America (Dutta \& Sahney 2016:942; Hallinger, 2003:329; Pan, Nyeu \& Chen 2015:493). The concept of instructional leadership originated from research by Edmonds in 1979, entitled, Effective Schools for the Urban Poor (Edmonds, 1979:15-24). This study identified a strong and directive principal leadership style focused on curriculum and instruction as a factor of success and effectiveness for elementary schools in poor urban communities. Moreover, the study revealed that the instructional role of principals in successful schools had the following characteristics: principals spent more of their time coordinating, controlling, supervising, and developing curriculum and instruction in the school (Hallinger, 2003: 331). The instructional principals or leaders were also more goal-oriented, and focused on the improvement of student academic out- comes and were also viewed as cultural builders (Hallinger, 2003: 333; Sarikaya \& Erdogan, 2016: 73). They sought to create an academic process that fostered high expectations and standards for students as well as for teachers. Thus, school leadership (that is, instructional leadership) was found to be an important factor for a successful education, teacher performance and student achievement (Edmonds, 1979: 21; Hallinger, 2003: 333; Pan et al., 2015: 493).

Instructional leadership is an educational leadership style that focuses on the following core responsibilities: school instruction, defining the school vision, mission and goals, managing the implementation of curriculum and creating a safe school (Abdullah \& Kassim, 2011: 3307; Stewong \& Prasertcharoensuk, 2013: 2865; Zorlu \& Arseven, 2016: 276). A study by King (2002: 62) asserted that the role of an instructional leader differed from that of a traditional school administrator by focusing on effective instruction and student achievement. Conventional heads of school tend to spend most of their time dealing with administrative duties, whereas school principals that are instructional leaders are charged with redefining their role to strive for excellence in education and become a primary leader in a community. Instructional leaders go beyond the traditional way of administrating the school; they spend more time focusing on developing knowledge and implementing the curriculum, as well as instructing and assessing (Jita, 2010: 853)

The most used conceptualisation of instructional school leadership was developed by Hallinger (2003: 332). Recently, Harris, Jones, Cheah, Devadason and Adams (2017: 213) used this instructional leadership model to study school principal practices in Malaysia. This model proposed three instructional leadership dimensions, such as: "defining the school mission, managing the instructional programmes and promoting a positive school learning climate". Because of its comprehensiveness, this study is based on Hallinger's (2000) instructional leadership model.

Defining the school mission is divided into two functions: framing the school's goals and communicating the school's goals. Framing the school goals are concerned with the principal's ability in working with staff to ensure that the school has clear and measurable goals that focus on the academic progress of its students. The principal has a role in determining the areas in which school staff should pay attention and allocate resources during a given school year. Successful instructional school principals set goals to enhance student achievement. School goals should take into consideration previous achievements of students, current school resources, teacher commitment and parental involvement. School targets are based on directives from higher authorities. The goal should also state measurably (Hallinger \& Murphy, 1985: 222; Hallinger et al., 2017: 227).

Communicating school goals is part of principals' core responsibilities. It ensures that the goals are widely known and supported throughout the school community (students, teachers, staff and parents). The way of communicating can be formal (goal statement, staff bulletins, articles in the principals or site-council's newsletter, curricular and staff meetings, parents and teacher conference, and assemblies) and informal interaction with the school community (Hallinger \& Murphy, 1985: 222; Hallinger et al., 2017: 227). 
In general, in this assumption, the principal has the responsibility of organising and preparing the initial school mission. Thereafter, school practitioners, such as teachers, staff, student, parents, educators and stakeholders, discuss the proposed mission, and after continuous discussions and agreement, the school mission is shared with the whole community. Managing the instructional programmes focuses on the coordination and control of instruction and curriculum. This dimension incorporates three leadership functions: supervising and evaluating instruction, coordinating the curriculum and monitoring student progress. Supervising and evaluating instruction are central tasks for the principals to ensure that the goals of the school are implemented in the classroom (Hallinger \& Murphy, 1985: 222). Principals get intimately involved in instructional supervision in the classroom and give support to the teacher. Continuous monitoring and feedback to the teacher are key activities to improve student performance. A school which focuses on curriculum, can be instructionally effective. To monitor student progress, the school should implement standardised criteria and referenced evaluation systems such as, assessments such as tests and examinations. Based on student test results, principals should discuss how to improve results with students and teachers (Hallinger \& Murphy, 1985: 223; Hallinger et al., 2017: 229).

Managing instructional progress requires principals to engage more in the activities of the schools' instructional development programme. It is important to monitor and support their teachers (Pont, Nusche \& Moorman, 2008: 26) but, in order for school principals to manage the curriculum and classroom activities, they must have knowledge and skill on both the content and the pedagogy. Managing instructional progress is a dimension of school leadership that assumes that principals have more responsibility in instructional development (Hallinger, 2003: 333; Harris et al., 2017: 213).

Promoting a positive school learning climate, according to Hallinger (2003: 333), is an important and fundamental activity to achieving the vision of the school. Instructional leaders who want to improve their student learning achievement are leaders who focus more time on the activities of managing teaching-learning time, supporting teachers in their professional development, motivating and rewarding teachers and students who achieve well, and promoting positive school learning conditions.

Staff development is linked with student achievement, and the principal has the responsibility of offering further education and continuous professional development opportunities to teachers. Principals should also maintain high visibility in the school. The visibility of the principal can promote more interaction between students and teachers and teachers and the principal. This condition is essential in creating a common understanding of school goals (Hallinger \& Murphy, 1985: 222). An important role played by principals in creating a positive learning climate in the school is rewarding, recognising and promoting both teachers and students for their efforts. Thus, maintaining the quality of education and providing an incentive for learning are crucial. For example, a student, especially in poor communities, needs reliable and continuous reward for work well done. The principal is the one who links the classroom and student rewarding systems in the school (Hallinger \& Murphy, 1985: 224; Hallinger, 2000; Hallinger et al., 2017: 232).
Generally, extensive literature on the subject, synthesised by Hallinger (2005: 233), explained that the role of instructional leaders focuses on activities such as (1) developing a shared vision and goals that target instruction, (2) participating with stockholders for school improvement, (3) creating an attractive and conducive school climate that motivates both teachers and students, (4) organising an effective implementation of the curriculum and monitoring student achievement, (5) setting reward and motivational strategies as the improvement of school goals and (6) supervising and monitoring according to the plan of the school to ensure continuous development.

Transformational school leadership. J.M. Burns (1979: 20) postulated that transformational leadership developed from the concept of political leadership. Burns underlined that there was an interactional relationship between a leader and followers. It is a way of leading by engaging, motivating, ensuring integrity and the morality of one another in the pursuit of a common achievement goal (Burns, 1979: 20). Based on the Burns' theory, B.M. Bass expanded the theory of leadership style by including transactional and transformational leadership styles and then further modified it to include the full range of leadership models (Bass, 1999: 9-32). The transformational school principal is the school leader who strives to inspire, motivate and coach followers toward the success and development of the school (Bass \& Riggio, 2006: 4; Northouse, 2016: 166; Wahab et al., 2014: 40). Transformational leadership comprises four components:

Idealised influence (charismatic), as it is related to a charismatic, ethical condition and personal behaviour of leadership. Leaders who display the behaviour of a role model for followers and who truly lead the way, are related to idealised influence (Bass \& Riggio, 2006: 5). Idealised influence leaders consider their followers' needs over the leaders' own needs (Bass, 1985: 40; Northouse, 2016: 167). The charismatic leader is an ethical role model and is valued and respected by their followers (Avolio \& Bass, 2002: 2; Northouse, 2016: 167). Thus, the school principal has an idealised influence characterised by respectable communication skills, honesty, loyalty and self-confidence (Gort, 2015), which enables leaders to obtain full commitment and performance from followers (Gill, 2006).

Inspirational motivation by leaders inspires behaviour and motivates followers through providing meaning (Avolio \&Bass, 2002: 2; Bass \& Riggio, 2006: 4; Menon, 2014: 511). Transformational leaders establish commitment and team spirit by inspiring, encouraging and setting a vision for followers (Northouse, 2016: 167; Yahaya \& Ebrahim, 2016: 197). It is believed that a leader displaying inspirational motivation has high expectations for followers. Such leaders inspire and motivate the followers by communicating a clear vision, aligning organisational goals as well as personal goals, and treating problems as opportunities from which to learn (Gill, 2006). Inspirational leaders are positive, motivated, energetic and passionate (Gort, 2015).

Intellectual stimulation stimulates transformational leaders' followers "to be innovative and creative by questioning assumptions, reframing problems and approaching old situations in new ways" (Avolio \& Bass, 2002: 2). Intellectual stimulation needs the leader's ability and intellectual creativity to address challenging questions and situations ensuring that followers are innovative and crea- 
tive in problem-solving and become actively involved in organisational decision making (Hoyt, Geothals \& Riggio, 2006; Limsila \& Ogunana, 2008). Followers are not publicly criticised, but are openly encouraged to create and innovate. B.M. Bass, B.J. Avolio, D.I. Jung and Y. Benson (2003) and P.G. Northouse (2016: 169) state that the leader who incorporates an intellectual stimulation quality ensure that followers participate in decision-making activities, which means that the leadership style is participatory. This style of leadership therefore encourages followers or subordinates to innovate and to create solutions for problems. Such leaders act as creative, open-minded and intelligent leaders (Gort, 2015).
Individualised consideration refers to the ability of leaders to understand and identify employee needs and manage these at individual level (Menon, 2014: 511). Addressing individual needs, perspectives and personal developments are core leadership behaviours of leaders displaying individual consideration skill (Hoyt et al., 2006; Limsila \& Ogunana, 2008). Such leaders facilitate the learning condition and develop the followers' capacity to demonstrate their higher potential. Empowerment activities such as coaching, mentoring, showing empathy and understanding followers and motivating them to become future leaders (Bass et al., 2003; Bass \& Riggio, 2006: 7; Gort, 2015) are some behaviour practices.

\section{METHODS}

Conceptual framework

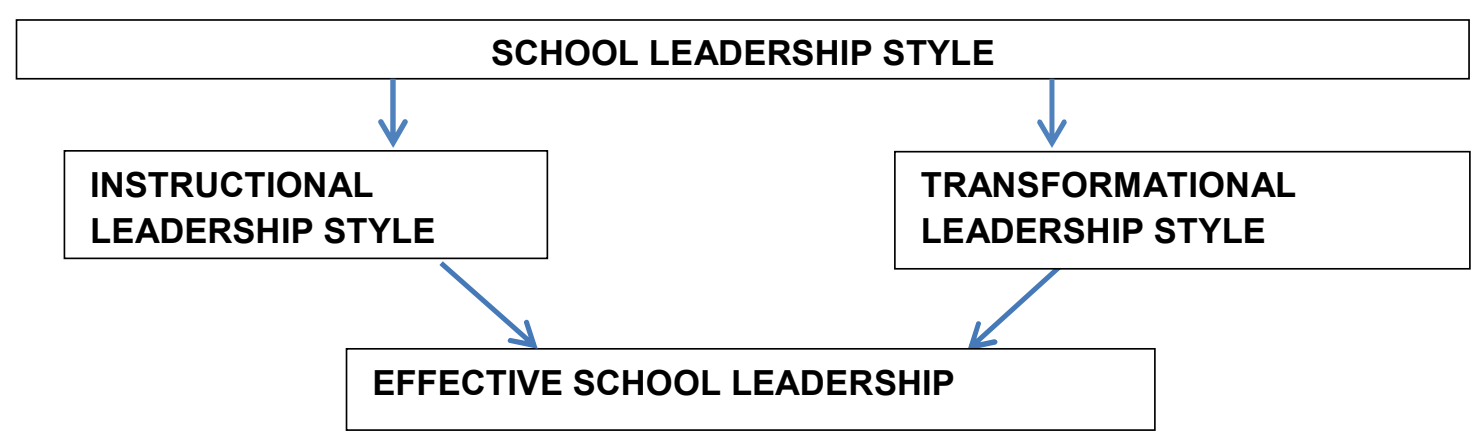

\section{Research Approach and Design}

To understand the research issues and to investigate the feeling of the participants in the study, this research used a qualitative research approach. This research employs a qualitative instrumental case study research design as it allows the researcher to understand the feelings and interpret the lived experiences of study participants

Sampling

The study area is Addis Ababa, Ethiopia. Addis Ababa City Administration public secondary schools' principals and teachers are the target population of the study. There are 65 public (government-owned) secondary schools (Addis Ababa Education Bureau, 2018). School principals and teachers in these schools make up the population for this study. Thus, the participants of this research are principals and teachers of the public secondary schools in Addis Ababa. The sample of the study was selected by purposive sampling, which allows the researcher to perform a qualitative investigation under study. In this research 34 participants were selected, 24 teaches and 10 principals from the 65 schools. The final sample size of the research is determined by the saturation of information extracted from study participants.

Data Collection

In this research, semi-structured individual in-depth interviews are used to collect data from participants. Before commencement of data collection, piloting of the interview will be conducted with three participants to revise and refine the interview tool to develop and minimise the unclear items in the interview questions. The research participants were interviewed using the semi-structure interview instrument prepared for this study, conducted in Amharic language.

Data Analysis

Data analysis was done concurrently with the data collection process. As the interviews conducted in Amharic (local) language, the interviews were translated to Eng- lish language after the audio recorded data transcription. In this research ATLAS.ti 8 qualitative data analysis software was used to facilitate the organisation of collected data. The data coding process and categorising of similar data codes were used for developing themes to determine the research findings.

Ethical Considerations

The study followed scientific research ethical procedures. Therefore, before data collected, ethical permission obtained from the Addis Ababa public secondary schools. Qualitative research is highly sensitive for ethical issues. Therefore, the research should protect the participants as human subjects. To protect participants, the researcher was followed necessary ethical procedures.

\section{RESULTS}

Principal leadership: instructional leadership theoretical view.

According to P. Hallinger et al. (2017: 227), instructional school leadership needs a principal who spends most of his/her time in implementing instructional supervision in classrooms, managing the curriculum and monitoring student progress. A principal has the responsibility of leading the school to improve student achievement and the school climate and ensure teacher job satisfaction. This needs a strategy of providing an incentive for school staff and students. In addition, the principal should safeguard against having instructional time consumed by the managerial duties (Shatzer, Caldarella, Hallam \& Brown 2014: 446). In exploring instructional leadership core activities, such as defining the school mission, managing the instructional programme and creating a positive school climate, this study found that school principals of the public secondary schools in Addis Ababa did not appear to meet the target of the core activities. 
Regarding building a shared mission among the school community, teachers perceived that principals do not communicate the school vision and mission to the teachers. In most cases, the school mission, objectives and plans are imposed. Even the principals do not internalise and fully believe in the plan, which is enforced from the top (education bureau) to the school. To support this idea, a principal said that:

We have posted the school's vision outside the school so anyone that wants to know does. Most of the school community have no idea what the vision is because there is not much focus on it (PP23)

The schools have missions, specific objectives and a plan in place. At the beginning of every education calendar, the school community discusses the school plan. In addition, the school principal posts the mission, vision and core values on the notice board. However, according to the teachers, no one gives this much attention. Teacher participant 4 confirmed that this is not enough to let the school communities to understand the vision and mission of the school. They lead the school in a traditional way (TP4).

Another teacher illustrated that the school mission was not communicated and shared amongst the school community:

I don't know what the vision and aim of the school is, maybe it is posted on the notice board outside the door but there is no effort to promote it (TP11)

Moreover, teachers concluded that the school mission was not shared amongst the school community. Thus, teachers suggested that principals should give attention to share the school mission by using various ways of communication.

Other than posting the vision and goals of the school on the walls, no efforts are made to educate the teachers and students about it. And there is a popular opinion among teachers that as long as they do their jobs, they don't need to bother with learning the vision and goals of the school. (TP14)

The second core dimension of instructional leadership is managing the instructional programme. Principals, as instructional leaders in the school, should conduct frequent classroom supervision, coordinating the curriculum and monitoring student progress. Supervising teachers indicate that there is support for the teaching and learning process which aligns with $\mathrm{P}$. Hallinger and J. Murphy (1985: 222) and P. Hallinger et al. (2017: 229), who explain that the central activities of instructional principals are supporting teachers by supervising and evaluating the classroom processed. The findings of this study revealed that supervision in public secondary high schools in Addis Ababa was done by different bodies, such as the education office, school principals and peers (within the department). However, teachers responded negatively to supervision support mentioning that supervision did not bring positive change to the teaching and learning process, to teaching methodology, nor to student achievement. Teachers reported that supervision was done only for the sake of reporting, paper work and finding fault with teachers and not for developmental reasons such as changing and improving the deficits found such as teaching methods, skills and knowledge. It was found that neither constructive feedback nor developmental training was given to teachers to close the gaps identified by the supervision. Regarding supervision, teachers participating in the research revealed that: The teacher gets supervision, but it's not enough. The aid that comes after the supervision is minimal (TP9). Another teacher confirmed that though supervision is carried out and some gaps identified, there is no support which will be given to teachers to fill the gap. (TP8).

Instructional leadership focuses on managing school instructional programmes to achieve the school mission and vision. However, the public-school principals do not seem to introduce the school vision to the school community. Little effort is made by the principal to share the school vision. A teacher stated as follows:

Vision is not known! As a teacher from what I observe, the teacher views his job just as teaching. There is no initiative on behalf of the principal to do orientation. The only time they assemble us is at the end of the year and the meeting has nothing to do with the teaching/learning process. Instead we focus on agendas coming from higher up in the system. I don't remember the last time we discussed the problems that we have here and their solutions. (TP10)

This finding is supported by a study conducted by H. Zorlu and A. Arseven (2016: 288), which concluded that the principals were not offering adequate support and in-service training for teachers who manifest a knowledge and skills gap.

One of the key dimensions of instructional leadership is managing the instructional programme. According to participants in the study, teachers are involved in curriculum development activities, curriculum evaluation and book review activities. However, participant teachers commented on the process of curriculum evaluation as it lacked continuity, and feedback on the curriculum was not given due attention by the higher officials to revise and improve the curriculum.

Teachers participate in curriculum evaluation. They evaluate books and give comments. However, it lacks continuity. I have never seen when principals facilitate this. The support that teachers receive to improve their professional competence is not based on planned and deliberate action which might fill the gap that teachers have. They only let teachers attend a higher institution that the Government-sponsored. (TP5)

Creating a positive school climate is the third key dimension of instructional leadership. Successful school leaders manage the instructional time, promoting professional development and enforcing academic standards for implementation of the curriculum effectively (Hallinger \& Murphy, 1985: 222; Hallinger et al., 2017: 229). In the instructional process, the planning aspect is significant. The principal, who follows the instructional plan effectively, will lead the learning and teaching process ensuing that learning time is adequate. Effective use of the time for instruction results in curriculum coverage within the given period. Thus, the instructional leadership of a principal is positively related to the improved achievement of students. However, this study discovered that teachers perceived that principals were unable to manage the instructional time effectively for several reasons. A participant teacher confirmed that:

The students cut classes and close the school, especially on holidays, by themselves. The students avoid coming to school a week before and a week after a holiday. The administration has done nothing to stop this. Instead, they focus on forcing the teachers to finish the yearly text book on time which puts pressure on us. This creates conflict between the teachers and the principals. (TP14)

It seems that leadership (administration) is unable to enforce attendance at school for the allocated academic year. Absenteeism during of the year by students compromises the teaching and learning process and puts 
pressure on teachers who are charged to complete the curriculum during the specified time.

\section{Principal leadership: transformational leadership theoretical view}

Transformational school leadership requires a leader who sets a clear organisational vision and inspires employees to perform at a higher level to achieve a common goal by creating a strong team spirit and trust (Bass \& Riggio, 2006: 4; Loon et al., 2012: 194; Nasra \& Heilbrunn, 2016). Practising a transformational leadership approach in schools leads schools towards improved performance (Balyer 2012: 583). The transformational leadership model has four components: idealised influence (the leader is a role model who takes initiatives and understands his followers), inspirational motivation (the leader motivates followers by setting clear vision, aligning organisational goals with personal goals), intellectual stimulation (the leader aims to inspire followers for performance beyond expectation) and individual consideration (the leader focuses on followers' individual needs, perspectives and personal development) (Northouse, 2016:169).

The study participants' perceptions regarding transformational leadership behaviour revealed that principals are not seen as transformational as they do not support their teachers, do not develop relationships with them, are not open to constructive criticism and do not behave with integrity. They found that their principals are not effective and as such, they do not have any trust in them as leaders. The teachers confirmed that: the teachers believe that directors do not listen to teachers' comments (TP4).

Another teacher stated that:

The school principal did not accept any comment. He always makes revenge on teachers who commented on him. Most teachers do not accept him as a principal. He divides teachers and creates conflicts. He gives training for teachers who support him. He would not even punish them in case they were absent or late. (TP6)

Teachers claim that the principals display favoritism when dealing with teachers, favouring ruling party members. For example, even when party member teachers are found to be ineffective in teaching and learning, they are awarded good performance evaluation score:

This evaluation method gets a lot of complaints because it awards better score to teachers who are political members and punishes the teachers that are not members even if their performance point is better. (TP10)

The transformational leadership style directs followers by motivating and setting a shared vision. It is also the process of supporting followers by considering their emotions, values, ethics, standards and long-term goals (Northouse, 2016: 169). Leaders who demonstrate transformational leadership behaviour bring a positive outcome to their followers' job satisfaction (Amin et al.,2013; Harris \& Jones, 2010; Ibrahim \& Wahab, 2012; Leithwood \& Jantzi, 2005; Pant, 2014). However, most principals lead their school as an industry that manufactures products. They lack the human aspect that is involved in the school process. Regarding this issue a teacher witnessed that:

Nowadays, teaching is becoming like factory production. Schools are like soap factories. Instead of being a gradual process, Education has become a field where you must do what you are told in order to fulfil the status quo. (TP9)

Principals, who have transformational leadership qualities, can inspire, motivate and identify the interest of their followers. Their communication ability, the way they nurture individuals and fill the gap of their followers leads the school to great achievement. In this study, a teacher was concerned about his principal's leadership practice: the principal has never tried to identify teachers' knowledge and the skills gaps that they have. (TP8)

Supporting this view, another teacher stated that:

There is no director (principal) who deliberately encourages teachers to have used their own initiative to teach effectively.

As a result, teachers' satisfaction will highly depend on their own initiatives. (TP7)

School principals are mostly engaged in the activities that are not related to instructional activities for quality education improvement. Their time is spent on routine activities such as reporting about school security issues, political activities, and teacher's availability in the school. The principals are more concerned with the peacefulness of the school each day. To maintain the school peace, principals have use teachers and students who are members of the ruling political party. As a result of this, teachers feel that their school is the place where the ruling party politically interferes. The principals also have a special connection with the teachers who belong to the ruling party.

There is no sense of ownership among the teachers who are out the political circle. They just want to do their assigned job and go home. There is a feeling of being ignored and segregated by the administration so they feel no responsibility towards the failure and the accomplishment of the school. (TP10)

Another teacher viewed school leadership as principals who were the messengers of the ruling political party in the school:

... as directors (principal) are assigned as a political appointment, their potential as a leader is under question. As there is a political perspective, there is no trust and good communication between director and teachers. It is not possible to bring the quality of education in this situation. (TP8)

School achievement is mainly dependant on the principal's leadership style. To have professional leaders who practise the behaviour of transformational leadership in schools, may inspire, motivate, create trust, and lead teachers to do their teaching effectively. Thus, principals in the Addis Ababa public secondary schools do not seem to practise transformational leadership. Quality education was not the priority of the school principals.

\section{Principal Leadership Behaviour}

Principals' leadership behaviour is vital for schools to achieve success (Zorlu \& Arseven, 2016: 1) and as previously discussed, successful school leadership focuses on interacting with people (Gurr, 2015:139) and motivating them to achieve the set goals. The findings of the study reveal that principal leadership behaviour, in addition to political interference in schools, is a cause for concern and seems to be related to job satisfaction and student achievement.

One of the issues raised was a non-participatory leadership style where teachers are excluded from the decision-making process:

The principal's leadership style is not inclusive to all teachers so that by itself is a reason for the poor teachers' job satisfaction. (TP21)

Principals' leadership practices (decision-making, teacher handling and school transformation) have created dissatisfaction among teachers. School planning and oth- 
er related activities adopt a top-down approach with decisions being made at the centre of the command post with no participation of the rest of the staff. Participant 17 indicated this issue as a military command:

Teachers are not involved in any of the decision makings. Most of the time, all the decisions are sent from high management. It looks like a 'military command'. (TP9)

Teachers reported that their school principals are not visionary. The school plan is mostly prepared by AACA without full participation and acceptance by teachers. Dictatorial leadership style is often practised by school principals. In theory, practicing transformational school leadership can lead teachers to a higher level of job satisfaction. Previous studies suggested that implementing transformational leadership styles in schools is positively related to teachers' school performance, student achievement and teacher job satisfaction.

Teachers do not have confidence in principals. They doubt principals' professional competence because they could not work on the school plan through coordinating and participating school community. The principals focus on punishing teachers for minor mistakes. They follow a dictatorial leadership style. (TP6)

A key factor in school leadership effectiveness is the involvement of the principal in creating a positive school climate (Hallinger \& Murphy, 1985) by protecting instructional time, promoting professional development, maintaining high visibility, providing incentives for teachers, enforcing academic standards and providing incentive for learning, all of which motivate teachers to perform well.

The participant teachers reported that their school principals had no basic skills to motivate teachers. Added to this, teachers perceived that their principals had no managerial and leadership skills to effectively lead their schools.

The management has done nothing to motivate teachers. They just sit in their offices in fear. They don't have the knowledge or skills to lead. Teachers are not satisfied because the management is unqualified. (TP11)

In contrast to what theory suggests, principals do not allocate enough time to lead the teaching and learning process in schools; their focus is political activities. In addition, principals have not developed good relationships with teachers and tend not to support them. As a result, teachers claim that principals' leadership styles are the main cause of low teacher job satisfaction. Participant 14 reported that:

Currently, teachers are forced to stick to their duties. There is no one who stands for teachers' right. The principals' leadership style is one of the main reasons for teachers' dissatis-

faction. School leaders focus on non-academic issues. (TP6)

The teachers reported that trust between principals and teachers has been eroded through time. As previously explained, the principals use students to spy on teacher activities in the classroom. Principals monitor classroom interactions and curriculum topics. Through time, teachers have developed a fear of discussing issues with their students, even though the issues are important and warrant discussion. As a result, teachers have lost confidence, academic freedom and autonomy. Atkinson (2000 in Dehaloo 2011:74) indicated that teachers' autonomy in schools refers to the amount of freedom given to the teachers to perform their responsibility following their job description. It is a prerequisite for teacher motivation and job satisfaction. For example:
... principals recruit students for political reasons and use the students as source of information in the school compound. This creates mistrust between teachers and the administration and it also contributes for lack of freedom. Since teachers assume that students might go back to the administration to report something out of context, it is difficult to discipline the students from the teachers' point of view. Currently, there is mistrust among the school community and as well as lack of freedom in the school which affect work motivation. (TP10) Performance evaluation by the school principals is another questionable leadership practice. Teachers are not evaluated based on pedagogical measurements such as teaching and learning activities. Teachers' pedagogical performances are seldom taken as an evaluation. In contrast, political activities such as participation in one-tofive grouping, co-curricular activities and teachers' attitude toward the ruling party are listed as the major criteria for performance evaluation of teachers.

Teachers who perform well and teachers who perform poorly are both treated equally. Because of this, we fail to see the point in trying to perform better. There is truly little encouragement in this school as compared to in other schools. (PP19)

Interestingly, another teacher pointed out that the principals themselves are not satisfied with their jobs. As a result, they cannot motivate teachers as they are not happy themselves. Principals are intensely pressurised by the dictates of the AACA and Woreda political cadres and in addition, are not in a position of authority, do not have the autonomy to run their schools as they would like to, are poorly paid and have very few benefits:

The school principal did not work to enhance teachers' satisfaction because the principal himself/herself is not satisfied with what he/she is doing. Any authority who does not know the profession can come any time and insult them (principals). They do not have freedom. Their salary is not enough. They do not have benefits. (TP4)

Moreover, a principal stated that teacher job satisfaction is mostly related to other factors than the leadership style of principals.

Leadership style may have some little role here in areas like trainings and motivational workshop so the teacher has a good view about his profession. The school leadership's role in the teachers' satisfaction is extremely limited it is those who are in charge of recruitment that play a huge role. (PP18)

According to the Herzberg's two-factor theory, extrinsic factors comprising work relationships, organisational polity, working conditions and job security, all relate to leadership behaviour and influence job satisfaction. This study found that school principals do not practise transformational leadership behaviour as they are constrained by the policies of the ruling party. As a result of their leadership style, schools do not run effectively and teachers often get dissatisfied. As reviewed in the literature, practising transformational leadership in schools improves teacher effectiveness and performance (Leithwood \& Sun, 2012: 420), commitment (Amin et al., 2013:105; Selamat et al., 2013: 570; Aydin et al., 2013: 807) and thus job satisfaction (Hariri et al., 2016: 590; Voon et al., 2011). E.A. Nir and L. Hameiri's research findings (2014: 210) recommend that school principals should not use sanctions and threats. The use of harsh powerbases is not likely to result in school effectiveness. On the contrary, T.A. Tesfaw (2014: 917) found that practising transformational leadership in schools was less likely related to teacher job satisfaction. 


\section{Conclusions}

School achievement highly depends on the leadership style of the principal. The study found that teacher job satisfaction and effectiveness of schools are positively related to instructional leadership. However, school principals participating in the study, did not fully apply an instructional leadership style. Instructional leadership has the domains of defining school mission, creating positive school climate and managing instructional programs. Even though, school principals have a school plan, vision and mission there was gap in communicating and sharing the mission to the school teachers. In addition, most principals were politically affiliated so that there was not a positive relationship between teachers and principals. Principals spent the majority of time on political activities, with the follow up and supervision of the teachinglearning process being a secondary task. As the result, there was low teacher job satisfaction and low student achievement.

Researchers reported that transformational leadership behaviour and instructional leadership style have a positive impact on teacher job satisfaction, work commitment and better school performance. In this study, as suggested by the teachers, transformational leadership is a favourable leadership style in order for schools to become effective in their activities. They also agreed that such leadership behaviour is strongly related to improving student achievement.

\section{Recommendations}

Despite attempts, an instructional leadership style as well as a transformational leadership style was seldom implemented. As these leadership styles were recommended by both principals and teachers, the government ought to work hard to equip school principals with these leadership styles through continuous professional development activities and in-service training. In addition, educational authorities at AACA Education Bureau should monitor, regulate and support principals' implementation of these leadership styles in their schools.

Added to the selection and appointment processes, appointed school leaders should be provisioned with continuous on-the-job training as well as continuous professional development activities. Furthermore, the government and the City Administration educational authorities should provide professional support to the school leaders in addition to their usual supervision and monitoring activities. It is also important for the school to build cooperation with universities and teacher training colleges for mutual professional development.

\section{Implications}

This study was undertaken before the political transition in the country. Currently Ethiopia has new government and government system. Thus, I recommend for further research on the political transition may change the school management and leadership practice.

\section{Conflict Interest}

The authors declared no potential conflicts of interest with respect to the research, authorship, and/or publication of this article.

\section{REFERENCES}

Abdo, H.A. (2000). Teacher incentives in the Middle East and North Africa Region: The shortcomings. Mediterranean Journal of Educational Studies, 6(1):107-122.
Abdullah, J.B. \& Kassim, J.M. (2011). Instructional leadership and attitude toward organizational change among secondary school's principal in Pahang Malaysia. Procedia Social and Behavioural Science, 15: 3304-3309. DOI: https://doi.org/10.1016/j.sbspro.2011.04.290

Addis Ababa Education Bureau. (2018). Education Statistics Annual Abstract. Addis Ababa. Retrieved from: http://www.aaceb.gov.et (Accessed: 24 September 2018).

Avolio, B.J. \& Bass, B.M. (2002). Developing potential across a Full Range of Leadership Cases on Transactional and Transformational Leadership. Lawrence Erlbaum Associates, Mahwah, NJ. DOI: https://doi.org/10.4324/9781410603975

Aydin, A., Sarier, Y.\& Uysal, S. (2013). The effect of school principals Leadership style on teachers' organizational commitment and job satisfaction. Educational Science: Theory \& Practice, 13(2): 806-811.

Balyer, A. (2012). Transformational Leadership Behaviour of School Principal: A Qualitative research based on teachers' perceptions. International Online Journal of Educational Science, 4(3): 581-591.

Bass, B.M, Avolio, B.J, Jung, D.I., \& Benson, Y. (2003). Predicting unit performance by assessing transformational and transactional leadership. Journal of Applied Psychology, 88(2): 207-218. DOI: https://doi.org/10.1037/00219010.88.2.207

Bass, B.M. (1999). Two Decades of Research and Development in Transformational Leadership. European Journal of Work and Organizational Psychology, 8(1): 9-32. DOI: https://doi.org/10.1080/135943299398410

Bass, B.M., \& Riggio, R.E. (2006). Transformational Leadership. 2nd edition. New York: Psychology Press.

Burns, J.M. (1979). Leadership. New York: Harper and Row.

Bush, T. \& Glover, D. (2014). School Leadership Models: What do we know. School Leadership \& Management, 34 (5): 553571. DOI: https://doi.org/10.1080/13632434.2014.928680

Center For British Teachers \& VSO. (2008). Study into Teacher Utilization in the Regions of Ethiopia (STURE). Addis Ababa: UNDP.

Davis, J.\& Wilson, S.M. (2000). Principals' efforts to empower teachers: Effects on teacher motivation and job satisfaction and stress. The Clearing House, 73(6):349-353. DOI: https://doi.org/10.1080/00098650009599442

Dutta, V.\& Sahney, S. (2016). School leadership and its impact on student achievement: The mediating role of school climate and teacher job satisfaction. International Journal of

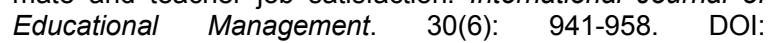
https://doi.org/10.1108/ijem-12-2014-0170

Edmonds, R. (1979). Effective Schools for the Urban Poor. Educational Leadership. 37(1):15-24.

Elias, S.H. \& Girum, S.T. (2018). Demand and Intake Capacity in Selected Departments of Postgraduate Studies in Addis Ababa University. Journal of Education and Practice. 9 (22): 2025.

Eyal, O.\& Roth, G. (2011). Principals' leadership and teachers' motivation. Journal of Educational Administration, 49 (3): 256-275.

Fekede, T.G. \& Tynjälä, P. (2015). Exploring teachers' motivation for teaching and professional development in Ethiopia. Journal of Studies in Education, 5 (2):169-186. DOI: https://doi.org/10.5296/jse.v5i2.7459

Gill, R. (2006). Theory and Practice of Leadership. London: SAGE.

Gort, J.A. (2015). A Qualitative Exploratory Single Case Study of Developing Leadership Behaviours in Business: The Role of Graduate School at Davenport University. (Ph.D.) Dissertation.

Hallinger, P. \& Murphy, J. (1985). Assessing the instructional management behaviour of principals. The Elementary School Journal, 86(2):217-248. DOI: https://doi.org/10.1086/461445 
Hallinger, P. (2000). A review of two decades of research on the principalship using the Principal Instructional Management Rating Scale. Paper presented at the annual meeting of the American Educational Research Association, Seattle, Washington.

Hallinger, P. (2003). Leading educational change: reflection on the practice of Instructional and Transformational Leadership. Cambridge Journal of Education, 33 (3):329-352. DOI: https://doi.org/10.1080/0305764032000122005

Hallinger, P. (2005). Instructional leadership and the school principal: A passing fancy that refuses to fade away. Leadership and Policy in Schools, 4 (3): 221-239. DOI: https://doi.org/$10.1080 / 15700760500244793$

Hallinger, P. (2007). Leadership for Learning: Reflections on the practices of instructional and transformational leadership. Paper presented, Seminar at East Asia University.

Hallinger, P., Walker, A., Nguyen, D.T.H., Truoug, T. \& Nguyen, T.T. (2017). Perspectives on principal instructional leadership in Vietnam: a preliminary model. Journal of Educational Administration, 55 (2): 222-239. DOI: https://doi.org/10.1108/jea-11-2015-0106

Harris, A., Jones, M., Cheah, K., Devadason, E. \& Adams, D. (2017). Exploring principals' instructional leadership practices in Malaysia: insights and implications. Journal of Educational Administration, 55 (2): 207-221. DOI: https://doi.org/10.1108/jea-05-2016-0051

Hoyt, C.L., Goethals, G.R. \& Riggio, R.E. (2006). Leader-follower relations: group dynamics and the role of leadership. The Quest for a General Theory of Leadership. DOI: https://doi.org/10.4337/9781847202932.00012

Ibrahim, M.S. \& Wahab, J.A. (2012). Educational Leadership. Bangi: University Kebangsaan Malaysia.

Jita, L.C. (2010). Instructional Leadership for the Improvement of Science and Mathematics in South Africa. ProcodiaSocial and Behavorial Sciences, 9(2): 851-854. DOI: https://doi.org/10.1016/j.sbspro.2010.12.247

King, D. (2002). The Changing Shape of Leadership. Educational Leadership, 59 (8): 61-63.

Leithwood, K. \& Sun, J. (2012). The nature and effects of transformational school leadership: A Meta-analytic review of unpublished research. Educational Administration Quarterly, 48: 387-423. DOI: https://doi.org/10.1177/0013161×11436268.

Limsila, K.\& Ogunlana, S.O. (2008). Performance and Leadership outcome Correlates of leadership style and Subordinate commitment. Engineering, Construction and Architectural Management, 15: 164-184. DOI: https://doi.org/10.1108/09699980810852682

Loon, M., Lim, Y.M., Lee, T.H. \& Tam, C.L. (2012). Transformational Leadership and Job-Related Learning. Management Research Review. 35 (3/4): 192-205. DOI: https://doi.org/10.1108/01409171211210118

Mengistu, G. K. (2012). Job Satisfaction of Secondary School Teachers in Ethiopia. PhD, Dissertation. University of South Africa.

Menon, M.E. (2014). The relationship between transformational leadership, perceived leader effectiveness and teachers' job satisfaction. Journal of Educational Administration, 52: 509528. DOI: https://doi.org/10.1108/jea-01-2013-0014

Nasra, M.A. \& Heilbrunn, S. (2016). Transformational leadership and Organizational leadership behavior in the Arab educational system in Israel: The impact of trust and job satisfaction. Educational Management Administration and Leadership, 44 (3): 380. DOI: https://doi.org/10.1177/1741143214549975
Nir, E.A., \& Hameiri, L. (2014). School Principals Leadership Style and School Outcomes. Journal of Educational Administration, 52 (2): 210-227. DOI: https://doi.org/10.1108/jea01-2013-0007

Northouse, P.G. (2016). Leadership: Theory and Practice. 7th edition. Thousand Oak, CA: SAGE.

Pan, H.W., Nyeu, F.Y. \& Chen, J.S. (2015). Principal instructional Leadership in Taiwan: Lessons from two decades of research. Journal of Educational Administration, 53 (4): 492511. DOI: https://doi.org/10.1108/jea-01-2014-0006

Pant, R. (2014). Literacy and Education for Sustainable Development and Women's Empowerment. UNESCO Institute for Life Long Learning.

Pont, B., Nusche, D., \& Moorman, H. (2009). Improving School Leadership V. 1: Policy and Practice. OECD. DOI: https://doi.org/10.1787/9789264167995-It

Price, H.E. (2012). Principal-teacher interactions how affective relationships shape principal and teacher attitudes. Educational Administrative Quarterly, 48 (1): 39-85. DOI: https://doi.org/10.1177/0013161x11417126

Sarikaya, N. \& Erdogan, C. (2016). Relationship between the instructional leadership behaviors of high school principals and teachers' organizational commitment. Journal of Education and Practice, 7 (3): 72-82.

Selamat, N., Nordin, N. \& Adnan, A.A. (2013). Rekindle teachers' organizational commitment: The effect of Transformational leadership behavior. Procedia Social and Behavioral Sciences, 90: 566-574. DOI: https://doi.org/10.1016/j.sbspro.2013.07.127

Shatzer, R.H., Caldarella, P., Hallam, P.R., \& Brown, B.L. (2014). Comparing the Effects of Instructional and Transformational Leadership on Student Achievement: Implications for Practice. Educational Management Administration \& Leadership, 42(2): 445-459. DOI: https://doi.org/10.1177/1741143213502192

Stewong, R. \& Prasertcharoensuk, T. (2013). The influence of instructional leadership of school administrators on school effectiveness. Procedia Social and Behavioral Science, (106:) 2859-2865. DOI: https://doi.org/10.1016/j.sbspro.2013.12.331

Tesfaw, T.A. (2014). The relationship between transformational leadership and job satisfaction: The case of government secondary school teachers in Ethiopia. Educational Management Administration \& Leadership, 42 (6): 903-918. DOI: https://doi.org/10.1177/1741143214551948

Voon, M.L., Lo, M.C., Ngui, K.S. \& Ayob, N.B. (2011). The influence of leadership styles on employee's job satisfaction in public sector organization in Malaysia. International Journal of Business, Management and Social Sciences, 2(1): 24-32.

Wahab, J., Fuad, C., Ismail, H.\& Majid, S. (2014). Headmaster transformational leadership and their relationship with teachers' job satisfaction and teachers' commitments. International Educational Studies, 7(13): 40-48. DOI: https://doi.org/10.5539/ies.v7n13p40.

Yahaya, R. \& Ebrahim, F. (2016). Leadership Styles and Organizational Commitment: Literature Review. Journal of Management Development, 35 (2): 190-216. DOI: https://doi.org/10.1108/jmd-01-2015-0004

Zorlu, H.\& Arseven, A. (2016). Instructional leadership behaviors of school administrations on the implication of secondary school curricula. International Journal of Higher Education. 5(1): 276-291. DOI: https://doi.org/10.5430/ijhe.v5n1p276 


\section{ЕЛІАС СЕБСБІ ГЕЙЛ,}

Університет Котебе, Коледж медичних наук та охорони здоров'я (Аддис-Абеба, Ефіопія) e-mail: eliassebsibe@gmail.com,ORCID 0000-0002-6989-0246

\section{ЯКІСНЕ ДОСЛІДЖЕННЯ ПРАКТИКИ НАВЧАЛЬНОГО КЕРІВНИЦТВА ТА ТРАНСФОРМАЦІЙНОГО ЛІДЕРСТВА В ДЕРЖАВНИХ ЗАГАЛЬНООСВІТНІХ ШКОЛАХ АДДИС-АБЕБИ (ЕФІОПІЯ)}

Результати діяльності навчального закладу тісно пов'язані з якістю та/або релевантністю обраного директорами стилю керівництва, а також його можливим впливом на рівень задоволеності вчителя своєю роботою. Директорам шкіл потрібно обрати оптимальний стиль керівництва, щоб надихати та заохочувати вчителів. Мета цього дослідження - дослідити практику керівництва державною загальноосвітньою школою в контексті теорій навчального керівництва та трансформаційних стилів керівництва. Встановлено, що обидві теорії охоплюють практики лідерства, що підвищують рівень задоволеності викладачів та досягнення учнів. Для підтвердження теоретичних висновків було проведено емпіричне дослідження, під час якого були опитані директори державних шкіл та вчителі (всього - 34 учасника, в тому числі 24 викладачі та 10 директорів із 65 шкіл Аддис-Абеби). Форма опитування - напівструктурні запитання. Аналіз даних проводився одночасно з проведенням сесій співбесіди. Для організації та генерації кодів та тем дослідження була використана комп'ютерна програма ATLAS.ti 8 (що дозволяє якісно аналізувати великі обсяги текстових, графічних, аудіо- та відеоданих). Висновками дослідження стали наступні положення: 1) директори державних шкіл Аддис-Абеби не до кінця реалізовують навчальну лідерську та трансформаційну стратегію в своїй роботі. Їм заважає втручання в роботу школи з боку влади. Головним критерієм призначення на посаду директора школи є не професійна компетентність чи результати діяльності, а відданість інтересам правлячої партії. Це дуже впливає на задоволеність та мотивованість учителів своєю роботою. Опитані вчителі підтвердили, що їх робота з викладання та навчання не отримує ефективної підтримки з боку керівників шкіл і зробили висновок, що шкільне керівництво не практикує в цілому ефективного стилю управління школою, подібного до стилю навчального та трансформаційного керівництва; 2) трансформаційна лідерська поведінка та стиль керівництва в навчанні позитивно впливають на задоволеність роботою вчителя, відданість роботі та кращі результати роботи в школі. Трансформаційне лідерство визначено респондентами опитування як сприятливий стиль керівництва для підвищення ефективності роботи шкіл та поліпшення досягнень учнів.

Ключові слова: державна загальноосвітня школа; навчальне керівництво; трансформаційне лідерство; ефрективне шкільне керівництво.

(C) Elias Sebsibe Haile

Надійшла до редакції: 21.08.2020

Прийнята до друку: 30.09.2020 